\title{
Effect of Transplanting Time and Cutting Size on Growth Parameters of Populus deltoids Under Nursery Conditions
}

\author{
Sourav Kumar* and H. S. Saralch
}

Dept. of Forest and Natural Resources, Punjab Agricultural University, Ludhiana, Punjab (141 004), India

\section{Corresponding Author}

Sourav Kumar

e-mail: sourav-fnr@pau.edu

\author{
Article History \\ Article ID: IJEP0284 \\ Received in $12^{\text {th }}$ February, 2019 \\ Received in revised form $20^{\text {th }}$ February, 2019 \\ Accepted in final form 23 $3^{\text {rd }}$ February, 2019
}

\begin{abstract}
The present study was carried out at the Experimental area of Dept. of Forest and Natural Resources, Punjab Agricultural University, Ludhiana, Punjab, India during the year 2016-17. The study was conducted to know the suitable time of transplanting and cutting size and to evaluate the growth parameters of plants under nursery conditions. Two cutting sizes i.e. large $15 \mathrm{~cm}$ and small $10 \mathrm{~cm}$ were used in the present investigation. First transplanting was done in the first week of May and second transplanting in the first week of June. The observations were recorded for various growth parameters of Populus deltoides under nursery conditions i.e. plant height, collar diameter, root length, root spread, shoot fresh and dry biomass. Cutting length had a pronounced significant effect on the growth parameters. It was observed that large cutting size exhibited significantly higher plant height $(2.40 \mathrm{~m})$, collar diameter (1.61), number of branches (7.44), root length (27.80 $\mathrm{cm})$, root spread $\left(612.36 \mathrm{~cm}^{2}\right)$, shoot fresh biomass $(558.89 \mathrm{~g})$ and dry biomass $(304.05 \mathrm{~g})$ than the small sized cuttings. The values of various growth parameters i.e. plant height, collar diameter, number of branches, root length, root spread, shoot fresh and dry biomass were higher in the cuttings transplanted in the month of May in comparison to June. The interaction effect of time of transplantingxcutting size had nonsignificant effect on all the parameters except collar diameter and root spread where the results were found to be significant.
\end{abstract}

Keywords: cutting size, Populus deltoides, time of transplanting

\section{Introduction}

Populus is an important genus meaning "people or masses" belonging to family Salicaceae. About 100 species of poplar exist in the world, $57 \%$ of which are originated from China (Zhang, 1999) and out of which six species are indigenous to India viz. Populus alba, P. ciliata, P. euphratica, P. gamblei, $P$. glauca and $P$. laurifolia. Individual plants in the genus Populus are either male or female. That is why, their seeds produce large number of hybrids in its natural distribution and hence, this character offers excellent opportunities for tree breeders for selection and improvement of individuals. Other countries which are undertaking poplar plantations are Australia, France, Germany, Hungary, Italy, Japan, Korea, Netherland and Romania. Exotic poplar species and improved clones were originally introduced in India as early as in 1950s from European countries and initially tried in Uttar Pradesh hills and later extended to Tarai (foot hills region) of the U.P. (now Uttarakhand) and to some other locations in the northwestern states viz. Punjab, Haryana, western Uttar Pradesh and some other parts in the adjoining states (Chaturvedi, 1982).
Populus deltoides has assumed the status of being commercially most useful species of the genus Populus in India (Kumar et al., 1999). Growth of poplar depends upon various factors such as clone, quality of planting stock, spacing of trees, intercrops, site quality, climate and management practices (Tewari, 1995). Farmers grow Poplar as one of the important tree components of agroforestry in north western states both as block and boundary plantation along with agricultural crops. This possesses most of the characters identified by King (1981) for tree species suitable for agroforestry systems-1) property of tolerance to pruning, 2) constricted crown, 3) light branching, 4) tolerance to side shade, 5) Efficiency in pumping nutrient/minerals and 6) leafs flushing or leaf fall that do not affect the ground flora. Hedge (1988) has also reported certain characters of successful agroforestry species in Indian conditions. Most of these characters (non- interfering with other crops, easy establishment with fast growth, easy litter decomposition, no toxic effect on soil and crops, possibility to regulate shade easily, multiple uses and high yield) are found in Populus deltoides.

In India, conventionally, Poplar is propagated through branch cuttings during winter i.e. mid-January to mid-February. Its 
initial nursery raising time overlaps with life cycle of many agricultural crops especially wheat at least for 2-3 months. To avoid any loss to the seasonal crops, it is necessary to develop some techniques so that poplar nursery can be continued on the same piece of land after harvesting wheat crop without any biological and economical loss of both same resource sharing crops. There are many factors influencing the propagation of cuttings, which include age, season of cutting collection, size, nutrient status of cuttings, pre-planting treatment, fungal infection, after planting management etc. The recommendations of nine new clones for plantation in Punjab have necessitated the standardization of nursery practices for these clones. The size and position of the cuttings in plant from where the cuttings are taken play a great role on growth and development of the plants. In general, longer cuttings taken from the lower parts of the plant produce better results, but with rise in demand for quality planting stock, the use of longer cuttings from basal portion only is not worthwhile. Therefore, in formulating working procedures for propagating superior poplar clones vegetatively. present study was planned to work out the appropriate cutting source from the donor plants (Chauhan et al., 2013). The present study has been planned to determine the suitable time of transplanting and size of cutting for raising poplar nursery.

\section{Materials and Methods}

The study was carried out in the experimental area of Department of Forestry and Natural Resources, Punjab Agricultural University, Ludhiana during 2016-2017. The study area is situated at $247 \mathrm{~m}$ above sea level and lies at $30^{\circ} 45^{\prime} \mathrm{N}$ latitude and $75^{\circ} 40^{\prime} \mathrm{E}$ longitudes, representing central zone of the Punjab. In general, the climate is sub-tropical with a long dry season from late September to early June and wet season from July to early September. May and June are the hottest months with intensive evapo-transpiration losses, whereas, December and January are the coldest months. The area receives an average rainfall of $732 \mathrm{~mm}$ per annum and $80 \%$ of total rainfall is received during July to September with an average of 37 rainy days. Mean maximum and minimum temperatures show considerable fluctuations during summer and winter. Maximum temperature of $45^{\circ} \mathrm{C}$ is common during summer and the minimum temperature of $1^{\circ} \mathrm{C}$ to $2^{\circ} \mathrm{C}$. Frosts is also quite common during December to February. The mean monthly temperature ranges from $12.9^{\circ} \mathrm{C}$ (January) to $32.2{ }^{\circ} \mathrm{C}$ (June). The topography of the study area is plain and characterized by inceptisol soils (USDA classification). The soil is deep, well drained, sandy loam in texture with low humus content and soil pH of 8.0. The irrigation is mainly done by tube wells.

Clone PL-1 collected from Research Farm of the Department of Forestry and Natural Resources, Punjab Agricultural University, Ludhiana (Punjab) was used in present study. The experiment was laid out using randomized block design. Two factors i.e. cutting size and transplanting time each having two levels was compared. Two cutting sizes were prepared i.e. $15 \mathrm{~cm}$ and $10 \mathrm{~cm}$. The cuttings of normal size $(20 \mathrm{~cm})$, were planted in the main field at a spacing of $60 \times 60 \mathrm{~cm}^{2}$ in the mid of February, 2016. The cuttings were planted by inserting the cuttings in soil leaving 2-3 buds above ground level. Simultaneously, the cuttings of $15 \mathrm{~cm}$ and $10 \mathrm{~cm}$ were planted in polythene bags in the nursery. The plants developed from cuttings in the polythene bags were transplanted twice in the field. First transplanting was done in the first week of May and second transplanting in the first week of June. The plants were irrigated regularly. So experiment had following treatments May transplanted (A1)+Large cutting (B1), May transplanted (A1)+Small cutting (B2), June transplanted (A2)+Large cutting (B1), June transplanted (A2)+Small cutting (B2) each was replicated four times. After one year of plantation six plants were selected from the each replication of each treatment for uprooting. Various growth parameters i.e. Collar diameter $(\mathrm{cm})$, Plant height $(\mathrm{m})$, Number of branches per plant, Root length $(\mathrm{cm})$, Root spread $\left(\mathrm{cm}^{2}\right)$, Shoot fresh and dry biomass (gm) were measured. Statistical analysis was carried out as per the procedures laid down for Factorial Randomized Block Design (Gomez and Gomez, 1984). Analysis of variance, critical difference (CD) and variance components were calculated for presentation and interpretation of results of the study. Data were analyzed with EDA software in factorial RBD.

\section{Results and Discussion}

\subsection{Effect of Time of Transplanting}

Data on the effect of time of transplanting on growth parameters of Populus deltoids are presented in Table 1.

Table 1: Effect of time of transplanting on the growth parameters of Populus deltoids under nursery conditions

\begin{tabular}{lccc}
\hline $\begin{array}{l}\text { Time of transplant- } \\
\text { ing/Parameters }\end{array}$ & May & June & $\begin{array}{c}C D \\
(p=0.05)\end{array}$ \\
\hline Plant height $(\mathrm{m})$ & $2.64(67)$ & $1.81(46)$ & 0.093 \\
Collar diameter (cm) & $1.76(75)$ & $1.22(52)$ & 0.052 \\
No. of branches & $7.56(69)$ & $6.00(54)$ & 0.36 \\
Root length (cm) & $28.55(72)$ & $23.74(60)$ & 0.79 \\
Root spread (cm $\left.{ }^{2}\right)$ & $635.54(54)$ & $457.38(39)$ & 34.92 \\
Shoot fresh biomass & $625(66)$ & $390.83(42)$ & 43.54 \\
(g) & & & \\
Shoot dry biomass & $339.61(69)$ & $211.42(43)$ & 25.03 \\
(g) & & & \\
\hline
\end{tabular}

Note: Figures in parenthesis exhibit percent of control

Data exhibited that time of transplanting has a significant effect on the growth of plant. Amongst the time of transplanting, cutting transplanted in May showed more growth than transplanting done in June. Data presented for all the growth parameters revealed that May transplanted cuttings exhibited significantly higher plant height and collar 
diameter to the extent of $2.64 \mathrm{~m}$ and $1.76 \mathrm{~m}$, respectively than June transplanted cuttings. May treatments cuttings also show significantly higher root length $(28.55 \mathrm{~cm})$, root spread $\left(635.5 \mathrm{~cm}^{2}\right)$, shoot fresh biomass $(625 \mathrm{~g})$ and dry biomass $(339.61 \mathrm{~g})$ in comparison to June transplanted cuttings. The better growth of May transplanted cuttings for all growth parameters might be due to the early transplanting in the field, which resulted in better space available in the field area for the root development. May transplanting exhibit more percent of control in all parameters as compare to the June transplanting.

Etemadi et al. (2013) studied the effect of transplanting date and method on growth and survival of three urban tree species in order to determine the appropriate transplanting conditions of these species. This is crucial for maintaining and protecting valuable urban trees in arid and semiarid climates. Based on the data, early-winter transplanting for white mulberry and smooth leaf elm trees and early-spring transplanting for eldarica pine trees resulted in greater survival rate and are therefore, considered as the best time of the year for transplanting the aforementioned trees in the Isfahan landscape.

It was also noticed that growth performance was better in the cuttings which were transplanted directly in the field in the month of February which is again a testimony that cuttings in the polythene bags can be grown only for limited period.

\subsection{Effect of cutting size}

The result pertaining to investigations with respect to the effect of cuttings size on different growth parameters of Populus deltoides have been presented in Table 1.

A critical review of the data revealed that cutting length had a pronounced significant effect on the growth parameters. It was observed that large cutting size exhibited significantly higher plant height $(2.40 \mathrm{~m})$, collar diameter $(1.61 \mathrm{~cm})$ and number of branches (7.44). Data presented for other characters (root length, root spread, shoot fresh biomass and dry biomass) revealed that large size cuttings exhibited significantly better root length $(27.80 \mathrm{~cm})$, root spread $\left(612.36 \mathrm{~cm}^{2}\right)$, shoot fresh biomass $(558.89 \mathrm{~g})$ and dry biomass (304.05 g) than the small size cuttings.

As noticed from the Table 2, the large size of cuttings showed superiority over small size cuttings with respect to the all growth parameters. It may be due to the test that large sized cuttings contain more carbohydrate reserve as compare to the small size cuttings resulting in better growth. Vigl and Rewald (2014) performed the experiment with 2 common SRC clones (Populus clone Max 4, Salix clone Inger) and 2 cutting length $(20 \mathrm{~cm}$ and $40 \mathrm{~cm})$. Above- and belowground biomass and leaf and root morphology were determined after one growing season. Longer cuttings produced more biomass but had a diverging influence on the shoot: root allocation of both clones. Long sized cuttings of Populus cl. Max produced more aboveground biomass,
Table 2: Effect of cutting length on the growth parameters of Populus deltoids under nursery conditions

\begin{tabular}{lccc}
\hline $\begin{array}{l}\text { Cutting length/ } \\
\text { Parameters }\end{array}$ & $15 \mathrm{~cm}$ & $10 \mathrm{~cm}$ & $\begin{array}{c}\mathrm{CD} \\
(p=0.05)\end{array}$ \\
\hline Plant height $(\mathrm{m})$ & $2.40(61)$ & $2.05(52)$ & 0.093 \\
Collar diameter $(\mathrm{cm})$ & $1.61(68)$ & $1.38(58)$ & 0.052 \\
No. of branches & $7.44(68)$ & $6.13(56)$ & 0.36 \\
Root length (cm) & $27.80(70)$ & $24.49(62)$ & 0.79 \\
Root spread (cm $\left.{ }^{2}\right)$ & $612.36(52)$ & $480.53(41)$ & 34.92 \\
Shoot fresh biomass & $558.89(59)$ & $456.94(49)$ & 43.54 \\
$\begin{array}{l}\text { (g) } \\
\text { Shoot dry biomass }\end{array}$ & $304.05(62)$ & $246.97(50)$ & 25.03 \\
(g) & & & \\
\hline
\end{tabular}

Note: Figures in parenthesis exhibit percent of control

mostly leaves, than $20 \mathrm{~cm}$ cuttings, while $40 \mathrm{~cm}$ Salix cl. Inger cuttings had more fine roots. Leaf and root morphology was only marginally influenced by cutting length. But choosing longer Populus $\mathrm{cl}$. Max cuttings might not be a good strategy when considering SRC establishment on more stress-prone sites, since their larger above-ground biomass will increase transpirational demand. Because of the lower shoot: root ratio, longer Salix cl. Inger cuttings seem to be more suitable to establish SRC on fields with (partially) restricted water and nutrient supply than shorter cuttings. Thus, planting difficulties and higher costs of longer cuttings may be offset by higher survival and greater aboveground productivity only in some clones. In the future, optimal cutting lengths must be evaluated not only for different environmental conditions but also for different SRC species/clones.

Sidhu and Dhillon (2007) conducted the field study to determine the effect of initial size of planting stock on poplar height, collar diameter and volume growth. The large sized cuttings stock attained significantly higher diameter and volume growth at all ages than those of small sized cuttings, whereas the superiority of former in plant height was only up to 3 years of age. The significant clonal variation was noticed for all growth traits for all ages.

\subsection{Interaction effect of time of transplanting $\times$ cutting size}

The data pertaining to the interaction effect of time of transplanting into cutting size on plant height, collar diameter, number of branches, root length, root spread, shoot fresh and dry biomass have been presented in Table 3 .

The interaction effect of time of transplanting into cutting size had non-significant effect on all the parameters mentioned in the Table 3, except collar diameter and root spread where the result were found to be significant. As evident from Table 3, large sized cuttings i.e. $15 \mathrm{~cm}$ transplanted in the month of May showed significantly better collar diameter as compare to the rest of treatments. Similarly, the root spread exhibiting higher values in large cutting transplanted in May 
Table 3: Effect of time of transplanting and cutting size on the growth parameters of Populus deltoides under nursery conditions

\begin{tabular}{|c|c|c|c|c|}
\hline \multirow[t]{2}{*}{ Parameters } & \multirow{2}{*}{$\begin{array}{l}\text { Time of } \\
\text { transplanting }\end{array}$} & \multicolumn{2}{|c|}{ Cutting length } & \multirow{2}{*}{$\begin{array}{c}C D \\
(p=0.05)\end{array}$} \\
\hline & & $15 \mathrm{~cm}$ & $10 \mathrm{~cm}$ & \\
\hline \multirow[t]{2}{*}{$\begin{array}{l}\text { Plant height } \\
\text { (m) }\end{array}$} & May & $\begin{array}{l}2.86 \\
(73)\end{array}$ & $\begin{array}{l}2.42 \\
(62)\end{array}$ & NS \\
\hline & June & $\begin{array}{l}1.94 \\
(50)\end{array}$ & $\begin{array}{l}1.68 \\
(43)\end{array}$ & \\
\hline \multirow{2}{*}{$\begin{array}{l}\text { Collar } \\
\text { diameter } \\
\text { (cm) }\end{array}$} & May & $\begin{array}{l}1.91 \\
(81)\end{array}$ & $\begin{array}{l}1.62 \\
(69)\end{array}$ & 0.073 \\
\hline & June & $\begin{array}{l}1.31 \\
(55)\end{array}$ & $\begin{array}{l}1.14 \\
(48)\end{array}$ & \\
\hline \multirow[t]{2}{*}{$\begin{array}{l}\text { No. of } \\
\text { branches }\end{array}$} & May & $\begin{array}{l}8.33 \\
(76)\end{array}$ & $\begin{array}{l}6.79 \\
(62)\end{array}$ & NS \\
\hline & June & $\begin{array}{l}6.54 \\
(59)\end{array}$ & $\begin{array}{l}5.45 \\
(49)\end{array}$ & \\
\hline \multirow[t]{2}{*}{$\begin{array}{l}\text { Root length } \\
(\mathrm{cm})\end{array}$} & May & $\begin{array}{c}30.39 \\
(77)\end{array}$ & $\begin{array}{c}26.72 \\
(68)\end{array}$ & NS \\
\hline & June & $\begin{array}{c}25.22 \\
(64)\end{array}$ & $\begin{array}{c}22.28 \\
(56)\end{array}$ & \\
\hline \multirow[t]{2}{*}{$\begin{array}{l}\text { Root spread } \\
\left(\mathrm{cm}^{2}\right)\end{array}$} & May & $\begin{array}{c}719.61 \\
(61)\end{array}$ & $\begin{array}{l}551.39 \\
(47)\end{array}$ & 49.38 \\
\hline & June & $\begin{array}{c}505.11 \\
(43)\end{array}$ & $\begin{array}{c}409.67 \\
(35)\end{array}$ & \\
\hline \multirow[t]{2}{*}{$\begin{array}{l}\text { Shoot fresh } \\
\text { biomass (g) }\end{array}$} & May & $\begin{array}{c}684.44 \\
(73)\end{array}$ & $\begin{array}{c}565.56 \\
(60)\end{array}$ & NS \\
\hline & June & $\begin{array}{c}433.33 \\
(46)\end{array}$ & $\begin{array}{c}348.33 \\
(37)\end{array}$ & \\
\hline \multirow[t]{2}{*}{$\begin{array}{l}\text { Shoot dry } \\
\text { biomass (g) }\end{array}$} & May & $\begin{array}{c}370.28 \\
(76)\end{array}$ & $\begin{array}{c}308.94 \\
(63)\end{array}$ & NS \\
\hline & June & $\begin{array}{c}237.83 \\
(48)\end{array}$ & $\begin{array}{l}185 \\
(38)\end{array}$ & \\
\hline
\end{tabular}

Note: Figures in parenthesis exhibit percent of control

as compare to the other treatments. Large sized cuttings transplanted in the month of May show higher value of all growth parameters as compare to the large sized cuttings transplanted in the month of June.

It may be due to the early transplanting in entire growing period facilitated early establishment and devoid of harsh climatic conditions especially high temperature. Plants grow faster in the field as compare to the cuttings raised in polythene bags.

\section{Conclusion}

The findings of the present experiment may lead to the conclusion that Transplanting time and Cutting length had a pronounced significant effect on the growth parameters. The large size cuttings, transplanted in the month of May was found to best in comparison to all other treatment in the present study.

\section{References}

Chaturverdi, A.N., 1982. Poplar farming in U.P., Uttar Pradesh Forest Department, Lukhnow, U.P.

Chauhan, S.K., Thakur, N.S., Sharma, R., 2013. Effect of cutting source and size on the poplar (Populus deltoides Marsh.) nursery performance. Journal of Tree Science 31, 81-85.

Etemadi, N., Nezhad, R.M., Zamani, N., Majidi, M.M., 2013. Effect of transplanting date and harvest method on growth and survival of three urban tree species in an arid climate. Arboriculture and Urban Forestry 39, 211-17.

Gomez, K.A., Gomez, A.A., 1984. Statistical procedures for agricultural research. John Wiley and Sons, New York, 680.

Hedge, N.G., 1988. Agroforestry under Indian condition. In: Advances in forestry research in India (Ed), Prakash R.. International Book Distributors, Dehradun, India, 119-126.

Kumar, D., Singh, N.B., Rawat, G.S., Srivastava, S., Mohan, D., 1999. Improvement of Populus deltoides Bartr. ex Marsh. in India - I: Present status. Indian Forester 125, 245 v63.

King, K.F.S., 1981. Concept of agroforestry. International Council for Research in Agroforestry, Narobi, Kenya, 15.

Sidhu, D.S., Dhillon, G.P.S., 2007. Field performance of ten clones and two sizes of planting stock of Populus deltoides on the Indo-gangetic plains of India. New Forests 34, 115-22.

Tewari, D.N., 1995. Agroforestry for increased productivity, sustainability and poverty alleviation. International Book Distributors, Dehra Dun, India, 799-801.

Vigl, F., Rewald, B., 2014. Size matters? -The diverging influence of cutting length on growth and allometry of two Salicaceae clones. Biomass and Bioenergy 60, 130-136.

Zhang, H., 1999. Poplar breeding, cultivation technologies and extension in China. APAFRI Publication Series, Kuala Lumpur, Malaysia, 35-37. 